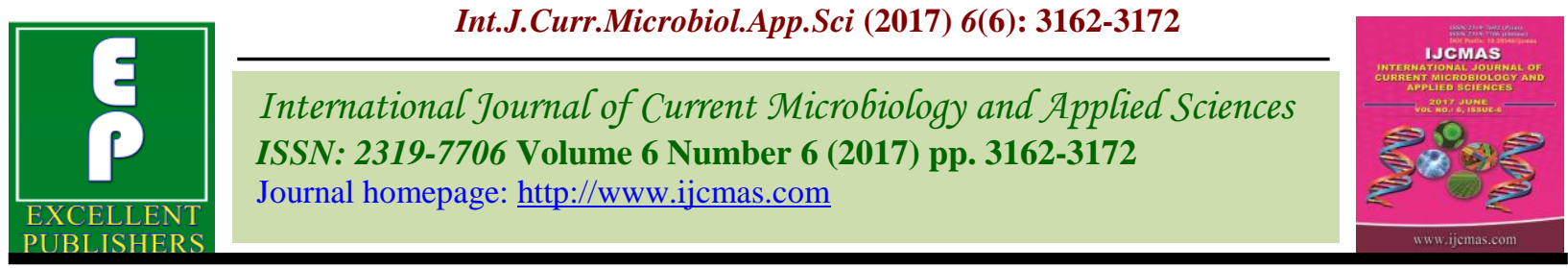

Review Article

https://doi.org/10.20546/ijcmas.2017.606.372

\title{
High Tech Nursery Management in Horticultural Crops: A Way for Enhancing Income
}

\author{
R.R. Singh ${ }^{1}$, L.K. Meena ${ }^{2}$ and Paramveer $\operatorname{Singh}^{3}$ \\ ${ }^{1}$ Department of Pomology, ${ }^{2}$ Department of Horticulture (Vegetable and Floriculture), \\ ${ }^{3}$ Department of Horticulture (Vegetable and Floriculture), BAU, Sabour-813210, \\ Bhagalpur, India \\ *Corresponding author
}

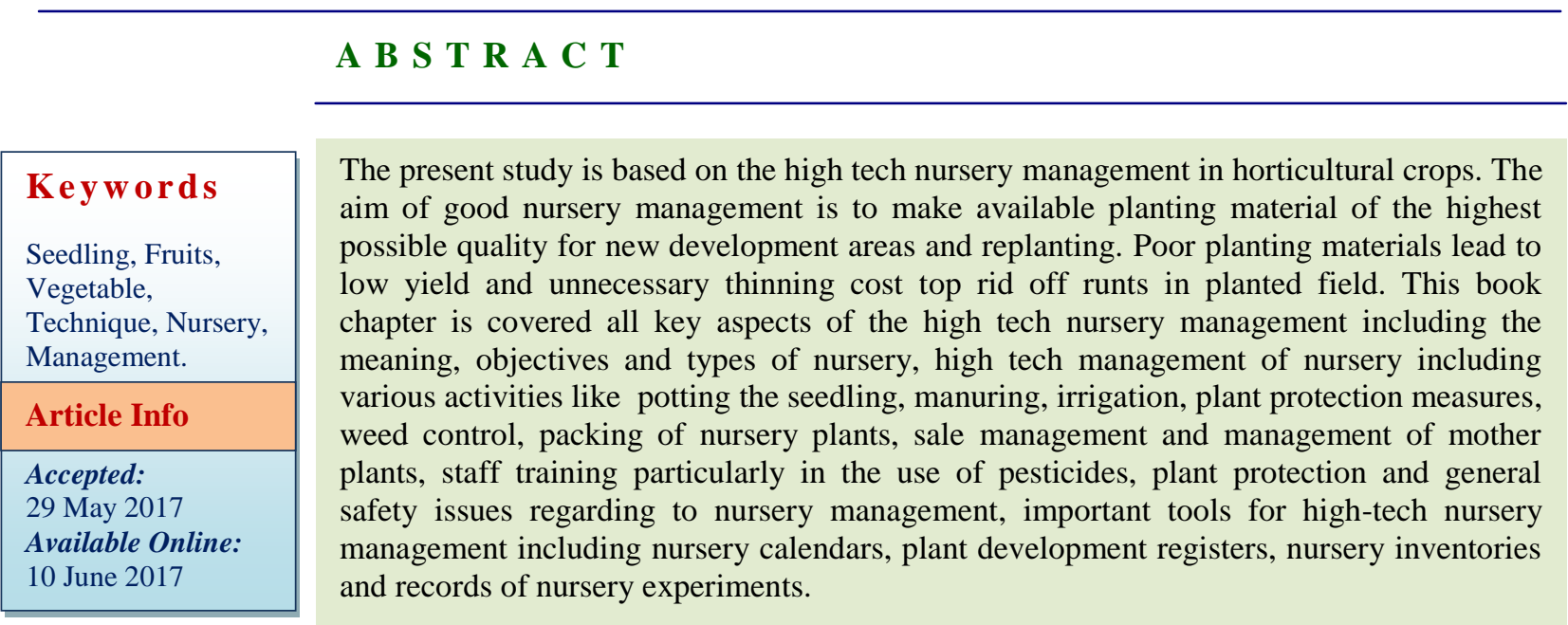

\section{Introduction}

India is endowed with a remarkably heterogeneous area characterized by a great diversity of agro climatic zones, allowing for production of a variety of horticultural crops such as fruits, vegetables, flowers, spices, plantation crops, root and tuber crops, and medicinal and aromatic crops. Agriculture is the backbone of our country and has a prime role in Indian economy. Agricultural sector provides livelihood to more than 65 percent of the labour force. Under agriculture sector horticultural crops play very important role to economy (Meena et al., 2013; Meena et al., 2016). It ranks second in fruits and vegetables production in the world, after China. As per
National Horticulture Database published by National Horticulture Board, during 2014-15 India produced 86.602 million metric tonnes of fruits and 169.478 million metric tonnes of vegetables. Horticulture is the science or art of cultivating fruits, vegetables, flowers, or ornamental plants. Etymologically, "horticulture" can be broken down into two Latin words: hortus (garden) and cultus (tilling). As William L. George explains in his definition as "Horticulture involves five areas of study". These areas are floriculture (includes production and marketing of floral crops), landscape horticulture (includes production, marketing and maintenance of 
landscape plants), floriculture (includes production and marketing of vegetables), pomology (includes production and marketing of fruits), and postharvest physiology which involves maintaining quality and preventing spoilage of horticultural crops." Horticulture is the cultivation of garden plants, fruits, berries, nuts, vegetables, flowers, trees, shrubs and turf. Horticulturists work for plant propagation, crop production, plant breeding, genetic engineering, plant biochemistry, plant physiology, storage, processing and transportation. They work to better crop yield, quality, nutritional value and resistance to insects, diseases, and environmental pollution. Horticulturalists use modern nurseries for the production of seedlings and mother plants. These plants are propagated through different methods such as seeds, inarching, budding, veneer grafting, patch budding and soft wood grafting.

Horticulture exports have helped the country to earn Rs 14,000 crore in 2011-12. Horticulture accounts for $30 \%$ of India's agricultural GDP from $8.5 \%$ of the cropped area. India's major exports include onion, mango pulp, fresh mangoes, dried walnuts, fresh grapes. India's biggest export markets are South Asian and Middle East Countries. India's share in the global market is insignificant - it accounts for $1.7 \%$ of the global trade in vegetables and $0.5 \%$ in fruits.

Twenty two types of fruits (e.g. banana, mango, citrus, apple, guava, grapes, pineapple, papaya, pomegranate etc.), 20 types of vegetables (e.g. potato, brinjal, tomato, tapioca, onion, cabbage, cauliflower, okra etc.), flowers (loose and cut) plantation crops (coconut, cashew nut, areca nut, cocoa), spices (e.g. mustard seed, chilli, turmeric, garlic, ginger, tamarind, coriander, cumin, pepper, fenugreek etc.) and some aromatic and medicinal plants (Singh, 2013) are being produced.
Nursery is defined as an area where plants are raised for eventual planting out. It comprises of nursery beds, paths irrigated channels etc. Nursery bed is defined as a prepared area in a nursery where seed is sown or into which seedlings or cuttings are raised. On the bases of kind of plants growing in them nursery beds are classified into seedling beds and transplant beds, seedlings, beds are those nursery beds in which seedlings are raised either for, transplanting in other beds or for planting out. A nursery which has only seedling beds i.e. in which seedlings are only raised for transplanting is called seedlings nursery. Transplant beds are those nursery beds in which seedlings raised in seedling beds are transplanted before planting out in forest. A nursery that has only transplant beds i.e. in which seedlings are transplanted in preparation for forest planting is called transplant nursery. In India separate seedling and transplant nurseries are seldom made in the same nursery. Generally whatever is grown in nursery for planting out is called nursery stock.

The aim of good nursery management is to provide planting material of the highest possible quality for new development areas and replanting. This aim is of the greatest important as the areas planted are likely to have a productive life span of 25 years or more. Poor planting materials will lead to low yield and unnecessary thinning cost top rid off runts in planted field. So, the selection of good planting materials and strict culling in nursery are the important step. The importance of the best quality planting material as an initial investment is a well realized factor for persons engaged in Horticulture field. So nurseries have great demand for the production of plants, bulbs, rhizomes, suckers and grafts. But in general good quality and assured planting material at reasonable price is not available. So persons having a skill of propagation of plants can go 
for this avenue as an agro-business of future. Seedling production is a major expense of afforestation and every effort should be made to produce good quality seedlings at a reasonable cost. To this end mastering the techniques of nursery operations is essential means high tech nursery management is very essential. (Mbora et al., 2008)

State of Indian Agriculture 2011-12 reported the increase in per capita availability of fruit (from 115 gram to 172 gram per day) and vegetables (from 236 gram to 312 gram per day) between 2001-02 and 2010-11. As per FSI (2011), the total forest cover increased and reached $692027 \mathrm{~km}^{2}(21.05 \%$ of geographic area) while the total tree cover has been estimated to be $90,844 \mathrm{~km}^{2}(2.76 \%$ of geographic area). Even though the agriculture production is in an upward trend, the increase in population, inflation and climate uncertainty warrants efforts towards sustainable agriculture.

The main suppliers of perennial tree seedlings are the departmental/government and industrial nurseries. They are producing seedlings and vegetative propagules to meet their own seedling demand and also supply them to public to meet their raw material demand. Mostly the vegetable and ornamental seedlings are produced by the farmers themselves, due to the market availability of improved seed and requirement of minimum inputs to establish them. Since the price of ornamental seedlings mainly depends on the buyer's interest, size of planting material, the small private nurseries mostly concentrate on the ornamental seedling/propagule production to fetch more profit.

The industrial nurseries are well equipped with infrastructure, manpower, automation and target to produce seedling/propagules of short rotation tree species to meet their factory raw material demand such as pulp and paper, plywood, small timber for furniture, juice, jam and pickle making. Hence, different kind of nurseries targets various end products. But nursery is pre requisite for meeting the quality seedlings demand and nursery management is a potential tool to execute the activity in successful way (Krishnan et al., 2014).

\section{Meaning, objectives and types of nursery}

\section{Meaning}

A nursery is a place where plants are propagated and grown to usable size. They include retail nurseries which sell to the general public, wholesale nurseries which sell only to businesses such as other nurseries and to commercial gardeners, and private nurseries which supply the needs of institutions or private estates. Some retail and wholesale nurseries sell by mail. Nurseries may supply plants for gardens, for agriculture, for forestry and for conservation biology. Some nurseries specialize in one phase of the process: propagation, growing out, or retail sale; or in one type of plant: e.g., groundcovers, shade plants, or rock garden plants. Some produce bulk stock, whether seedlings or grafted, of particular varieties for purposes such as fruit trees for orchards, or timber trees for forestry. Some produce stock seasonally, ready in springtime for export to colder regions where propagation could not have been started so early, or to regions where seasonal pests prevent profitable growing early in the season

\section{Definition of nursery}

A nursery is a place where plants are grown, nurtured and sold out. Generally, various commercial crop growers require a good quality saplings or grafts of genuine type. It can also defined nursery is a place or an establishment for raising or handling of young 
vegetable or fruit seedlings until they are ready for more permanent planting."

\section{Objectives of nursery}

It occupies an important place in artificial regeneration. The following objectives for which nursery is generally made, clearly bring out its importance.

1. Some important species do not seed ever year. Plantations of these species can be raised annually, only by sowing all available seeds in nursery to raise seedlings to be planted out various years.

2. Some species grow very slowly and if the seeds of these species are sown directly in plantation, the seedlings are most likely tobe suppressed by weeds and ultimately killed. Therefore, slow growing spices are generally raised in nursery and planted out, only when the seedlings are not liable to be damaged by weeds.

3. Success of road side avenue plantations depends largely on planting tall and sturdy plants which can be only obtained from nursery.

4. Plantations of some species, when raised by direct sowing are not so successful when raised by transplanting their seedlings. In such cases, nursery is an essential part of artificial regeneration to these species.

5. The best method for introduction of exotics, tropical Pines, Poplars Eucalyptus etc. is only by, planting and therefore nursery is very essential for them.

6. Planting of nursery grown plants is the surest method of artificial regeneration on poor and barren sites.

7. Causalities in plantations have to be replaced either for the year of planting or in the next year. Sowing done in the gaps is liable to be unsuccessful as a result of suppression from weeds and cannot catch up the growth as from, original sowing. Therefore, replacement of causalities is always done by planting nursery grown plants or stumps and so nursery is very essential for causality replacement also.

\section{Benefit of raising seedlings in nursery}

1. It is very convenient to look after the tender seedlings

2. It is easy to protect the seedlings from pests and diseases

3. Economy of land usage (duration in the main field is reduced)

4. Valuable and very small seeds can be raised effectively without any wastage

5. Uniform crop stand in the main field can be maintained by selecting healthy, uniform and vigorous seedlings in the nursery itself.

\section{Types of nurseries}

Nurseries are categorized in different ways.

\section{Based on time duration}

\section{Temporary nursery}

This type of nursery is established in or near the planting site. Once the seedlings for planting are raised, the nursery becomes part of the planted site. There are sometimes called "flying nurseries". This type of nursery is developed only to fulfil the requirement of the season or a targeted project. The nurseries for production of seedlings of transplanted vegetables and flower crops are of temporary nature. Likewise temporary arrangement for growing forest seedlings for planting in particular area can also be done in temporary nursery.

\section{Permanent nursery}

This type of the nursery is placed permanently so as to produce plants continuously. These nurseries have all the permanent features. The 
permanent nursery has permanent mother plants. The work goes on continuously all the year round in this nursery. These can be large or small depending on the objective and the number of seedlings raised annually. Small nurseries contain less than 100,000 seedlings at a time while large nurseries contain more than this number. In all cases permanent nurseries must be well-designed, properly sited and with adequate water supply.

\section{Based on type of plants produced}

\section{Fruit plant nurseries}

In this nursery, seedlings and grafts of fruit crops are developed.

\section{Vegetable nurseries}

In this nursery, seedlings of cauliflower, cabbage, brinjal and tomato are prepared.

\section{Flowers plants nurseries}

The seedlings of flowering plants like gerbera, carnation, petunia, salvia, rose, chrysanthemum, coleus, aster, dianthus are developed in this nurseries.

\section{Forest nurseries}

The seedlings of plants useful for forestation like pine, oak, teak, eucalyptus, casuarinas are prepared and sold.

\section{Miscellaneous nurseries}

In such type of nurseries plants with great economic value, rare and medicinal, herbal plants are propagated. In this nursery plants like geranium, rose, calendula, and marigold are propagated. Planning of nursery one has to decide which type of nursery is to be started. At the same time the durations and type of plants propagated should be finalized.

\section{Selection of site}

Site is the basic requirement of a nursery. Site is a place upon which one can produce seedlings of plants.

Qualities of a good site are

Nearness of road

Near a habitat

Suitable climate

Neither shady nor exposed area

Sufficient sunlight

Good irrigation facilities

Good soil condition

Good transport facility

\section{Management of nursery}

Nursery plants require due care and attention after having either emerged from the seeds or have been raised from other sources like rootstock or through tissue culture technique. Generally they are grown in the open field under the protection of Mother Nature where, they should be able to face the local environment. It is the duty and main objective of a commercial nursery grower to supply the nursery plants with suitable conditions necessary for their development and growth. This is the major work of management in the nursery which includes all such operations right from the emergence of young plantlet till them are fully grown-up or are ready for uprooting and transplanting in the main fields.

\section{Potting the seedling}

Before planting of sapling in the pots, the pots should be filled up with proper potting mixture. Now a day's different sizes of earthen pots or plastic containers are used for propagation. For filling of pots loamy soil, sand and compost can be used in 1:1:1 proportion. Sprouted cuttings, bulbs, corms or polythene bag grown plants can be transferred in earthen pots for further growth. All the 
necessary precautions are taken before filling the pots and planting of sapling in it.

\section{Manuring and irrigation}

Generally sufficient quantity of nutrients is not available in the soil used for seedbed. Hence, well rotten F.Y.M / compost and leaf mould is added to soil. Rooted cuttings, layers or grafted plants till they are transferred to the permanent location, require fertilizers. Addition of fertilizers will give healthy and vigorous plants with good root and shoot system. It is recommended that each nursery bed of $10 \mathrm{X} 10 \mathrm{~m}$ area should be given $300 \mathrm{gm}$ of ammonium sulphate, $500 \mathrm{gm}$ of Single super phosphate and $100 \mathrm{gm}$ of Muriate of potash. Irrigation either in the nursery beds or watering the pots is an important operation. For potted plants hand watering is done and for beds low pressure irrigation by hose pipe is usually given. Heavy irrigation should be avoided.

\section{Plant protection measures}

Adoption of plant protection measures, well in advance and in a planned manner is necessary for the efficient raising of nursery plants. For better protection from pest and diseases regular observation is essential. Disease control in seedbed:- The major disease of nursery stage plant is "damping off". For its control good sanitation conditions are necessary. Preventive measures like treatment with $50 \%$ ethyl alcohol, $0.2 \%$ calcium hypo chloride and $0.01 \%$ mercury chloride is done. These treatments are given for 5 to 30 minutes. Some of the seed treatments are as follows:

\section{Disinfection}

The infection within the seed is eliminated by use of formaldehyde, hot water or mercuric chloride.

\section{Hot water treatment}

Dry seeds are placed in hot water having a temperature of $480 \mathrm{C}-550 \mathrm{C}$ for $10-30$ minutes.

\section{Protection}

In dry seed treatment organo mercuric and non-mercuric compounds like agallal, aretan -6 , and tafasan-6. For this the seeds are shaken within the seed container. While in wet method, the seeds are immersed for certain period in liquid suspension.

\section{Soil treatment}

Soil contains harmful fungi, bacteria, nematodes and even weeds seeds, which affect the growth and further development of plant. These can be eliminated by heat, chemical treatment. For that soil is disinfected by heating to the temperature of about $600 \mathrm{C}$ for 30 minutes.

\section{Chemical treatment}

The chemicals like formaldehyde, methyl bromide, chloropicrin, vapam are used. Other diseases like rust, powdery mildew, leaf spot, bacterial blight, yellow vein mosaic are also observed. For control of these diseases Bordeaux mixture, Carbendazime, Redomil can be used. Tricoderma viride a biofungicide can also be tried out.

\section{Weed control}

Weeds compete with plants for food, space and other essentials, so timely control of weeds is necessary. For weed control weeding, uses of cover crops, mulching and use of chemicals (weedicides) are practiced. Pre-emergence weedicides like basaline or post-emergence weedicide like 2; 4-D and roundup are useful. 


\section{Measures against heat and cold}

The younger seedling is susceptible to strong sun and low temperature. For protection from strong sun, shading with the help of timber framework of 1 meter height may be used. Net house and green house structures can also be used.

\section{Packing of nursery plants}

Packing is the method or way in which the young plants are tied or kept together till they are transplanted. So they have to be packed in such a way that they do not lose their turgidity and are able to establish themselves on the new site. At the same time, good packing ensures their success on transplanting. For packing baskets, wooden boxes, plastic bags are used. In some parts of the country banana leaves are also used for packing the plants with their earth ball. This is useful for local transportation.

\section{Sale management}

In general the main demand for nursery plants is during rainy season. A proper strategy should be followed for sale of nursery plants. For that advertisement in local daily newspapers, posters, hand bills, catalogue and appointment of commission agents can be followed.

\section{Management of mother plants}

Care of mother plants is necessary so as to get good quality propagules and scion. A. Labeling and records B. Certification C. Irrigation D. Fertilization E. Pruning F. Protection from pests and diseases Collection and development of new mother plants Fruit Nurseries

\section{Another best way to manage tech nursery}

A vital part of nursery management is planning the production schedules and data collection. As we know that whole agriculture sector is seasonal and perishable in nature and in agriculture nursery production is highly seasonal. This is particularly marked when producing trees for agro forestry research, as the demand for species or numbers of seedlings will vary considerably depending on current research priorities. Flexibility and planning are therefore essential.

There are four main tools for planning nursery operations

A nursery calendar to help plan necessary actions and purchases of seed, supplies and equipment.

A plant development register for collecting species-specific information about seed treatment, germination requirements and duration, plant development, special requirements for potting substrate, watering, shading or disease control.

A nursery inventory to keep track of the species and numbers of seedlings in different stages of development.

A record of ongoing nursery experiments.

All four can be maintained in tabular form designed for ease of data capture on to computer programs. Computerized systems have increased the flexibility of data collection and analysis, making it easy for a nursery manager to correlate the collected information to necessary actions rapidly.

\section{Tools for high-tech nursery management}

1. Nursery calendars

2. Plant development registers

3. Nursery inventories

4. Records of nursery experiments 
These are needed for production management as well as for research. We also discuss the significance of staff training, particularly in the use of pesticides, plant protection and general safety issues regarding to nursery management.

\section{Planning tools nursery calendar}

A nursery calendar is a very essential tool in nursery planning. The date for sowing seeds can be calculated by counting backwards from the anticipated date of planting, taking into consideration the number of days needed for germination and further seedling development until the right stage for planting. Different species have different requirements for the planting out period (before or during the rains).

The time in the nursery also depends on the site on which the seedlings are to be planted. Seedlings for drier sites may need to be larger and need more time in the nursery. Customers might need to be reminded of this when they order plant material to meet certain deadlines. It is also worth anticipating problems with poor germination and/or damping-off to allow time to sow a second time.

Once a nursery calendar has been developed, it will help greatly in making decisions about the need for extra labour and requisition of supplies. Consider the likely delays in procuring and shipment of goods, especially when ordering from abroad. Place orders early enough to allow timely arrival.

\section{Plant development register}

For plant development register we should keep a register for each species by seed lot, with information about seed sources used, pre-treatment's, sowing date, time to germination, percentage of germination, percentage of germinants pricked out, potting substrate, microsymbionts used with its origin and type, plant development and condition under which produced.

Include pests encountered and control treatments, if any, as well as data of plant and/or substrate nutrient analyses. All this information is important for nursery research and might later help explain unexpected results. It can also be used to compare results with published information and alert you to possible problems originating in the nursery, for example if the development is much slower than is reported elsewhere. It might open additional research areas, for example it might lead to trying different substrates, shading or fertilizer treatments. Good documentation about species handling and development is also necessary when staff changes.

\section{Nursery inventory}

A well-kept and up-to-date nursery inventory helps to assess whether the nursery is operating as planned, and whether demands are being met. Your inventory should list all plants currently in the nursery by bed or frame number, and details of delivery of seedlings, including the site, name of owner and site conditions. It can be an important tool to record feedback from the planting sites and can then help to determine whether seedlings have the right quality for the sites on which they are planted.

\section{Record of experiments}

An up-to-date record of past and ongoing nursery experiments is advisable. Simple experiments testing new potting mixtures, watering regimes, seed pretreatments etc. should be part of normal nursery management and, without accurate records of these, valuable information is likely to get lost.

Example of calculating amount of seed 


\section{needed}

In the above case, 800 trees of each species will be planted. To estimate the number of seeds to germinate, remember that:

Seed germination $(\mathrm{G})$ is $75 \%$

Variation in germplasm is relatively low, but expect to cull $10 \%$ (C) at pricking out due to poor development

Allow a $15 \%$ margin in germination calculations for plants that need to be replaced (R) at a later stage

Seedlings needed (S) for each species: 800 Add for germination failure (GF): Sx100/G Ô $800 \times 100 / 75=1067$

Add for culling at transplanting (CT): $\operatorname{GFx}(100+\mathrm{C}) / 100$ Ô $1067 \times(100+10) / 100=$

\section{4}

Add for replacing at outplanting (RO): $\operatorname{CTx}(100+\mathrm{R}) / 100$ Ô $1174 \mathrm{x}(100+15) / 100=$ 1350

Total seeds needed for each species 1350. Given the seed weights for L. leucocephala (20 000/kg), L. diversifolia (26 000/kg) and $L$. trichandra (34 000/kg), $67.5 \mathrm{~g}, 51.3 \mathrm{~g}$ and $39.2 \mathrm{~g}$ respectively are needed.

\section{Example of a nursery calendar}

The researcher wants a Leucaena species trial planted with seedlings of about $20 \mathrm{~cm}$ size on about 15 April. The nursery manager has calculated the researcher's requirements as shown below.

\begin{tabular}{|l|c|c|c|}
\hline \multicolumn{1}{|c|}{ Particulars } & $\begin{array}{c}\text { Leucaena } \\
\text { leucocephala }\end{array}$ & $\begin{array}{c}\text { Leucaena } \\
\text { diversifolia }\end{array}$ & $\begin{array}{c}\text { Leucaena } \\
\text { trichandra }\end{array}$ \\
\hline days needed from pricking out to planting out & 100 & 110 & 90 \\
\hline days needed from germination to pricking out & 12 & 12 & 10 \\
\hline days needed from sowing to germination & 8 & 8 & 8 \\
\hline $\begin{array}{l}\text { safety margin in case of poor germination or } \\
\text { damping off }\end{array}$ & 15 & 15 & 15 \\
\hline total days needed & 135 & 145 & 123 \\
\hline sowing date & 1 Dec. & 21 Nov. & 13 Dec. \\
\hline
\end{tabular}

Figure.1 Primary nursery

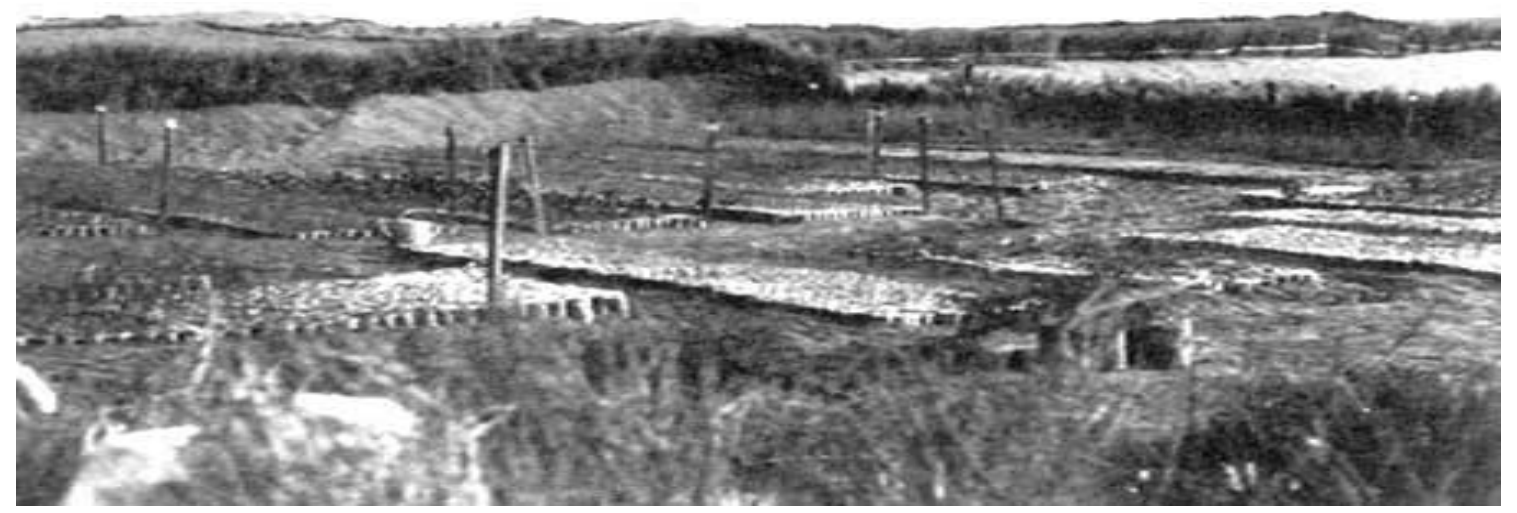


Figure.2 Permanent nursery

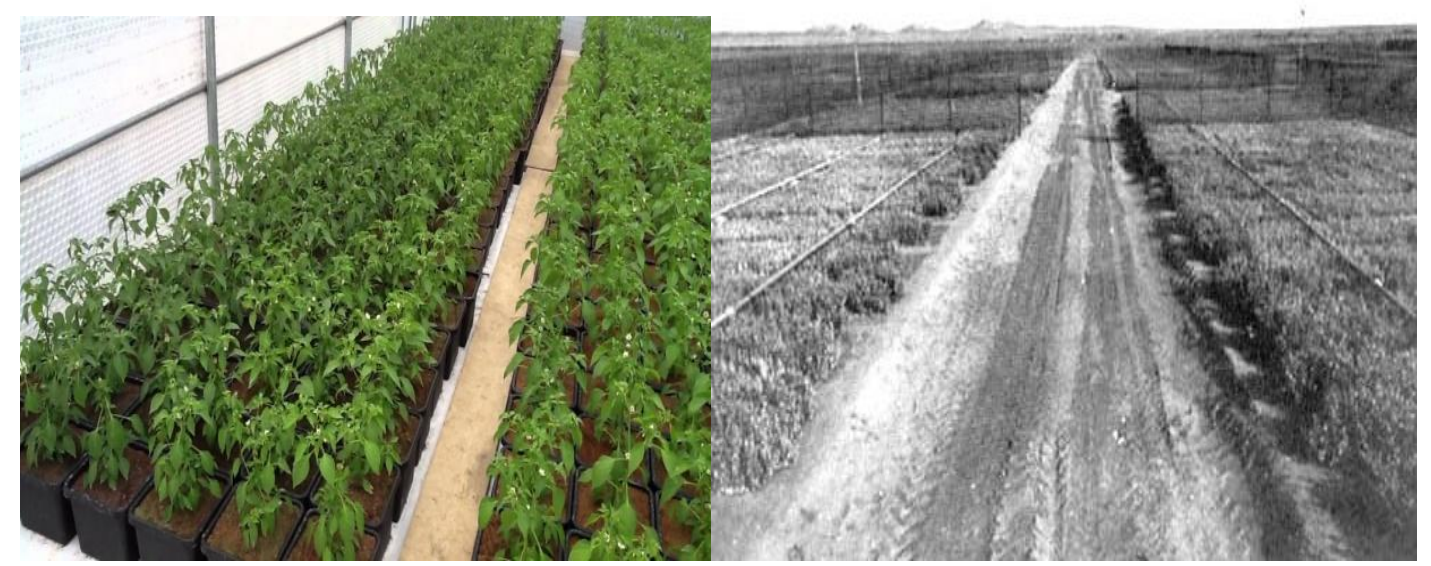

\section{Staff training}

A good nursery operation relies on continuity of staff that is professional, careful and honest. Although the casuals or technical workers do most of the work described here, everyone in the nursery ought to have as much knowledge about agro forestry tree propagation as possible. Understanding even in a simplified way the processes in a germinating seed, a rooting cutting or a growing seedling, and the importance of high humidity, watering, shading, etc. will help prevent many errors in daily work. Only when all workers feel that they are part of the nursery operation, when they understand the part they play and when they feel proud of it, can a tree nursery work efficiently and productively. All workers, not only those applying the chemicals, ought to know the basics of handling pesticides. Use gloves and safety equipment this should be standard practice and not something to laugh about. Staff training can take the form of scheduled courses or of regular (weekly, monthly) staff meetings covering a particular topic. This can be reinforced by repeating explanations of techniques during work.

It is concluded that the aim of good nursery management is to provide material of the highest possible quality for new development areas and replanting. The importance of good nursery practices cannot be over-emphasized. The nursery should be maintained at the highest standard to ensure only healthy, vigorous and uniform palms are planted in the field. Good planting materials will produce higher yield productivity for life span 25 years or more and any shortcomings in the planting materials will be of long term significance. Nursery care is therefore essential as it provides a cheap and good background for the seedlings to develop before field planting. So, the selection of good planting materials and strict culling in nursery are the important step. It also provides an opportunity to cull the poor seedlings. Smallscale tree nurseries and their managers have an important role in ensuring the sustainable development of rural communities. It is essential that they obtain access to the knowledge, skills and resources necessary to maintain and enhance their capacity to produce the seedlings which form an integral part of the local agroforestry systems.

\section{References}

Apeda.gov.in/apedawebsite/six_head_product/F FV.htm

Http://hasryc.blogspot.in/2012/02/nurserymanagement.html

Http://oer.nios.ac.in/wiki/index.php/Nursery_an d_Nursery_Management

Https://en.wikipedia.org/wiki/Plant_nursery

ILO (1989) Tree nurseries. An illustrated technical guide and training manual. Special Public Works Programmes booklet no. 6. Geneva, Switzerland: 
International Labour Organization. 127 pp.

Krishnan, P.R., Kalia, R.K., Tewari, J.C. and Roy, M.M. (2014) Plant Nursery Management and Plant Nursery Management: Principles and Practices, Central Arid Zone Research Institute, Jodhpur, 40pp.

Kumar. N., (1997) Introduction to Horticulture. Rajalakshmi Publications, 28/5 - 693, Vepamoodu Junction, Nagercoil. Pp: 15.47- 15.50 .

Landis, T.D., Tinus, R.W., McDonald, S.E., and Barnett, J.P. (1994) Nursery Planning, Development and Management. Vol. 1, the container tree nursery manual. Agriculture Handbook 674. Washington, DC, USA: US Department of Agriculture, Forest Service. $188 \mathrm{pp}$.
Mbora, A., Lillesø, J.P.B., and Jamnadass, R. (2008) Good Nursery Practices: A Simple Guide (ISBN: 978-92-9059-235-8). Nairobi. The World Agroforestry Centre. $36 \mathrm{pp}$.

Meena, L.K., Bairwa, S.L., Kumari, $M$ and Wadhwani, M.K. (2016) Performance of Onion in Bihar - An economic analysis, Economic Affairs 61(2): 299-304.

Meena, L.K., Sen, C. and Bairwa, S.L., Jhajharia and Raghuwanshi, N.K. 2013. Economics of Garlic Production in Baran District of Rajasthan; Break Even Analysis, Asian Journal of Agriculture and Rural Development 3(10): 697-701.

Singh, A. (2013) Department of Agriculture, Cooperation and Farmers Welfare (DACFW) Government of India (GOI)

Www.agriinfo.in/?page $=$ topicandsuperid $=2$ andt opicid $=1633$

\section{How to cite this article:}

Singh, R.R., L.K. Meena and Paramveer Singh. 2017. High Tech Nursery Management in Horticultural Crops: A Way for Enhancing Income. Int.J.Curr.Microbiol.App.Sci. 6(6): 3162-3172. doi: https://doi.org/10.20546/ijcmas.2017.606.372 